\title{
Pengaruh Partisipasi Penganggaran Pada Senjangan Anggaran Dengan Gaya Kepemimpinan Dan Karakter Personal Sebagai Variabel Pemoderasi
}

\author{
I Putu Suardi Antara Putra Mendi ${ }^{1}$ \\ Herkulanus Bambang Suparsto ${ }^{2}$ \\ ${ }^{1,2}$ Fakultas Ekonomi dan Bisnis Universitas Udayana (Unud), Bali, Indonesia \\ e-mail: putramendi369@yahoo.com
}

\begin{abstract}
ABSTRAK
Seluruh organisasi didalam beroperasi mempunyai tujuan jelas yang berfungsi menjadi panduan didalam melakukan kewajiban bagi masing-masing pegawainya. Penelitian ini bertujuan untuk mengetahui pengaruh gaya kepemimpinan dan karakter personal dalam memoderasi hubungan antara partisipasi penganggaran pada senjangan anggaran. Pendekatan yang dipakai didalam penelitian berikut yaitu pendekatan kuantitatif yang memiliki bentuk asosiatif kausalitas. Objek penelitian dalam penelitian ini adalah senjangan anggaran. Metode penentuan sampel responden dalam penelitian ini menggunakan metode purposive sampling. Jumlah responden yang digunakan sebagai sampel penelitian adalah 80 orang. Metode pengumpulan data yang digunakan adalah dengan cara penyebaran kuesioner. Teknik analisis data yang digunakan adalah Moderated Regression Analysis (MRA). Hasil penelitian ini adalah Partisipasi penganggaran berpengaruh negatif dan signifikan pada senjangan anggaran. Gaya kepemimpinan dan karakter personal memperkuat pengaruh partisipasi penganggaran pada senjangan anggaran.
\end{abstract}

Kata kunci : Penganggaran, kepemimpinan, karakter personal.

\begin{abstract}
Every company in carrying out its operations has clear objectives as a guideline in carrying out its duties by each of its employees. This study aims to determine the effect of leadership style and personal character in moderating the relationship between budgetary participation on budgetary slack. The approach used in this study is a quantitative approach in the form of associative causality. The object of research in this study is budgetary slack. The method of determining the sample of respondents in this study using a purposive sampling method. The number of respondents used as the study sample is 80 people. Data collection methods used are by distributing questionnaires. The data analysis technique used is Moderated Regression Analysis (MRA). The results of this study are that budgetary participation has a negative and significant effect on budgetary slack. Leadership style and personal character strengthen the influence of budgetary participation on budgetary slack.
\end{abstract}

Keyword : Budgeting, leadership, personal character.

\section{PENDAHULUAN}

Seluruh organisasi didalam melaksanakan pengoperasiannya mempunyai tujuan yang jelas berguna untuk pedoman didalam melakukan tugas bagi tiap-tiap pegawainya. Organisasi menjadi perlu mempunyai sebuah pengendalian manajemen sebagai jaminan mencapai tujuan organisasi supaya lebih efektif serta 
I Putu Suardi Antara Putra Mendi dan Herkulaus Bambang Suprasto. Pengaruh ...

efisien. Satu diantara banyak elemen penting didalam sistim pengendalian manajemen yaitu anggaran. Anggaran adalah alat bantu manajemen didalam melakukan alokasi terbatasnya sumber daya serta sumber dana yang dipunyai perusahaan dalam pencapaian tujuan, anggaran tidak hanya perencanaan finansial tentang biaya serta pendapatan didalam sebuah pusat pertanggungjawaban, tapi memiliki fungsi lain untuk alat pengendalian, koordinasi, komunikasi, evaluasi kinerja juga motivasi didalam sebuah perusahaan (Halikiya, 2009:1).

Anggaran berfungsi sebagai alat pengukur kinerja perusahaan, serta dapat digunakan sebagai alat untuk mempengaruhi dan memotivasi manajer dan karyawan agar senantiasa bertindak secara efektif dan efisien sesuai dengan tujuan yang ingin dicapai. Penelitian Hopwood (1972) dalam Lucyanda (2018) menunjukkan bahwa karyawan yang dievaluasi dengan budget cenderung mengalami ketegangan dan kekhawatiran dalam pekerjaan, sehingga timbul fenomena manipulasi data akuntansi secara berlebihan. Hal ini terjadi karena pada dasarnya banyak karyawan memiliki sifat alami manusia yang ingin selalu dinilai baik kinerjanya oleh atasan. Kondisi tersebut cenderung dapat menimbulkan keinginan karyawan untuk memanipulasi anggaran perusahaan atau dengan kata lain banyak karyawan yang ingin dinilai baik kinerjanya sehingga banyak yang melakukan budgetary slack.

Senjangan anggaran merupakan satu diantara sekian kendala didalam proses menyusun anggaran. Budgetary slack dapat diartikan sebagai perbedaan diantara anggaran yang dinyatakan serta diestimasi anggaran paling baik yang secara jujur bisa dilakukan prediksi. Anthony dan Govindarajan (2007:289) 
menyatakan bahwasannya budgetary slack sebagai berbedanya jumlah anggaran yang diajukan oleh bawahannya dengan banyaknya estimasi paling baik daripada peusahaan. Fenomena budgetary slack didalam dunia nyata seringlah terjadi serta membentuk masalah juga kerugian yang tinggi pada perusahaan. Budgetary slack mampu dilaksanakan dengan memperkecil pemasukan ataupun memperbesar pengeluaran dari yang seharusnya. Secara teoritis budgetary slack yang terjadi berfungsi untuk memudahkan tercapainya apa yang diharapkan. Kondisi ini bila terjadi secara terus menerus akan menurunkan profit dan perusahaan tidak akan mampu menghasilkan pendapatan secara optimal.

Riset tentang pengaruh partisipasi anggaran pada senjangan anggaran sudah sering dilaksanakan, tetapi dari hasil beberapa riset itu memberikan temuan yang memiliki perbedaan antara lain partisipasi penganggaran memiliki pengaruh positif signifikan pada senjangan anggaran, hasil itu adalah hasil riset dari Antle (1985), Eppen (1985) serta Falikhatun (2007). Beberapa peneliti yang memiliki pendapat bahwasannya partisipasi penganggaran mempunyai pengaruh positif juga signifikan terhadap senjangan anggaran antara lain adalah Veronica dan Komang (2009), Armaeni (2012), Apriadinata dkk. (2014) dan Lestari (2015). Hasil riset beberapa peneliti diatas memberikan bukti bahwasannya partisipasi yang tinggi didalam proses perumusan anggaran bisa memberi akibat kesenjangan anggaran yang besar pula. Selain itu penelitian yang dilaksanakan oleh Lowe dan Shaw (1968), Lukka (1988) dan Young (1985) dalam Ikhsan (2007) juga menunjukkan hasil yang positif dimana partisipasi anggaran juga kesenjangan anggaran memiliki hubungan yang positive. Hasil dari penelitian oleh Mahadewi 
I Putu Suardi Antara Putra Mendi dan Herkulaus Bambang Suprasto. Pengaruh ...

(2014), Ariawan (2015), Desmayani (2016) dan Arista (2016) menyebutkan bahwa partisipasi penganggaran berpengaruh positif terhadap senjangan anggaran. Hal ini berarti bahwa, semakin tinggi tingkat partisipasi bawahan dalam proses penyusunan anggaran maka semakin tinggi pula tingkat senjangan anggaran yang akan dilakukan.

Sejumlah peneliti lain malah memberikan pendapat yang berbeda-beda, hasil penelitian yang tidak sama ditunjukkan oleh sekian peneliti yaitu (Onsi, 1973), (Dunk, 1993), (Camman, 1976), (Baiman, 1982) dan (Collins, 1978) menyatakan bahwasannya partisipasi didalam menyusun anggaran bisa membuat berkurangnya senjangan anggaran (budgetary slack). Hal ini terjadi karena bawahan membantu memberikan informasi pribadi tentang prospek masa depan sehingga anggaran yang disusun menjadi lebih akurat. Penelitian yang dilaksanakan oleh Camman (1976), Merchant (1985) dan Onsi (1973) didalam Latuheru (2005) yang memiliki pendapat bahwasannya partisipasi anggaran serta kesenjangan anggaran memiliki hubungan yang negatif, dimana partisipasi yang ditandai dengan komunikasi positif diantara para manajer bisa menurunkan budgetary slack. Hasil penelitian yang dilaksanakan oleh Ramdeen et al. (2007), Sujana (2010), Karsam (2013), Resen (2014), Nitiari (2015), dan (Anggraini \& Sulistyowati, 2010) yang menunjukkan hasil empiris bahwasannya partisipasi penganggaran berpengaruh negatif terhadap senjangan anggaran.

Memberi pernyataan bahwasannya perbedaan hasil penelitian itu bisa diselesaikan lewat pendekatan kontiijensi. Hal ini dilaksanakan dengan memasukkan variabel lainnya yang diperkirakan akan memberi pengaruh 
partisipasi penganggaran pada senjangan anggaran (Govindarajan, 1986). Oleh sebab itu, di penelitian berikut ditambah variable gaya kepemimpinan dan karakter personal yang diduga memiliki pengaruh antara partisipasi penganggaran pada senjangan anggaran. Partisipasi anggaran merupakan proses yang menggambarkan individu-individu terlibat dalam penyusunan anggaran dan mempunyai pengaruh terhadap target anggaran dan perlunya penghargaan atas pencapaian target anggaran tersebut (Falikhatun 2007). Sedangkan, gaya kepemimpinan yaitu cara orang agar memberi arahan kepada orang lainnya hingga orang itu dengan iklas mengikuti kehendaknya supaya tujuan perushaan bisa dicapai (Luthans, 2008).

Motivasi didalam penelitian berikut yaitu agar melakukan pengujian kembali faktor apa sajalah yang memberikan pengaruh seorang manager didalam membuat terciptanya senjangan anggaran. Masih adanya beberapa kontradiksi serta ketidak konsistenan di riset sebelumnya membuat penelitian serupa tentang pengaruh partisipasi penganggaran pada senjangan anggaran berikut masih menarik agar dilaksanakan. Perbedaan hasil daripada penelitian sebelumnya pula jadi salah satu faktor mengapa peneliti melaksanakan riset pada topik ini. Selain itu penelitian berikut memakai lokasi penelitian yang berbeda daripada penelitianpeneltian sebelumnya. Berdasar kepada latar belakang yang sudah diuraikan, dapat dibuat rumusan masalah penelitian seperti berikut: Apakah partisipasi penganggaran berpengaruh pada senjangan anggaran? Apakah gaya kepemimpinan dapat memperkuat atau memperlemah pengaruh partisipasi penganggaran pada senjangan anggaran? Apakah karakter personal dapat 
I Putu Suardi Antara Putra Mendi dan Herkulaus Bambang Suprasto. Pengaruh ...

memperkuat atau memperlemah pengaruh partisipasi penganggaran pada senjangan anggaran? Berdasarkan pokok permasalahan di atas, maka tujuan penelitian ini adalah sebagai berikut: Untuk mengetahui dan mendapatkan bukti empiris tentang pengaruh partisipasi penganggaran terhadap senjangan anggaran. Untuk mengetahui pengaruh gaya kepemimpinan didalam memoderasi hubungan antara partisipasi penganggaran terhadap senjangan anggaran. Untuk mengetahui pengaruh karakter personal didalam memoderasi hubungan antara partisipasi penganggaran terhadap senjangan anggaran.

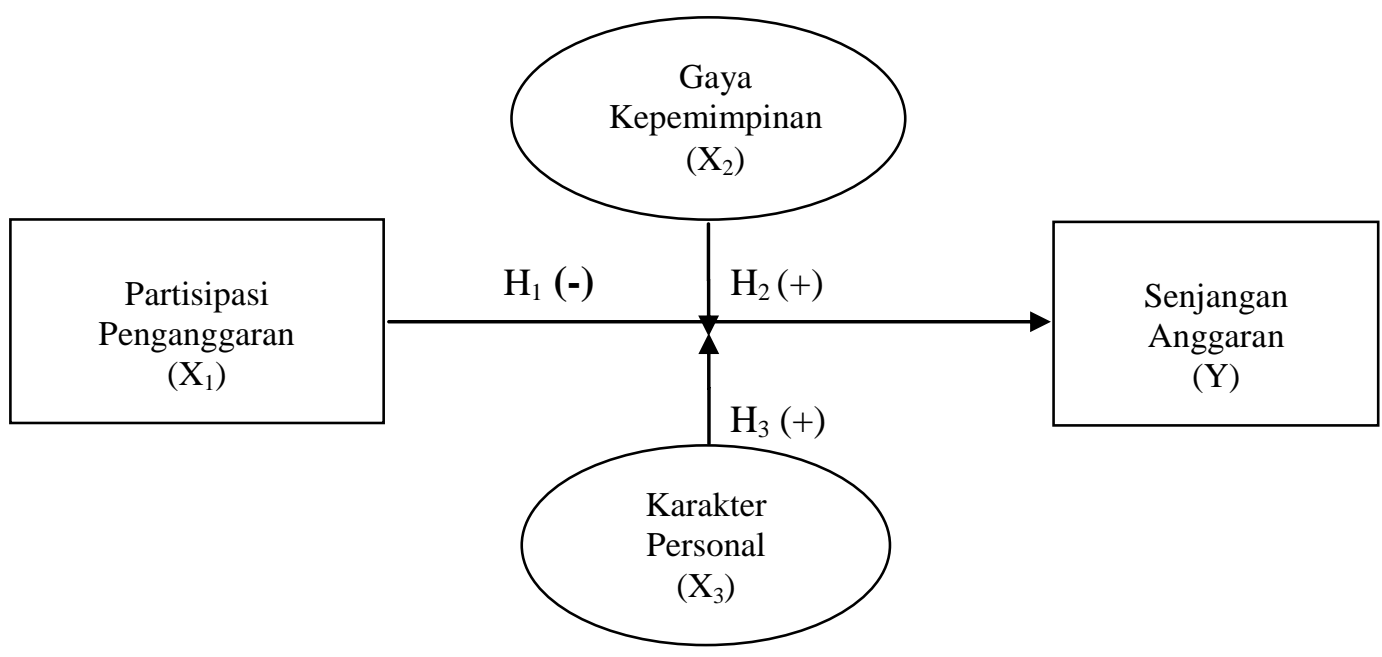

Sumber: Data diolah, 2019

\section{Gambar 1. Kerangka Konseptual}

Penelitian berikut membahas mengenai pengaruh partisipasi penganggaran pada senjangan anggaran dengan gaya kepemimpinan serta karakter personal sebagai variabel pemoderasi, hingga model penelitian ini bisa tergambar diatas.

Sesuai dengan kerangka konseptual pada Gambar 1. dapat dijelaskan bahwa hubungan Partisipasi Penganggaran $\left(\mathrm{X}_{1}\right)$ terhadap Senjangan anggaran $(\mathrm{Y})$ dalam penelitian ini akan dimoderasi dengan variabel Gaya Kepemimpinan $\left(\mathrm{X}_{2}\right)$ dan Karakter Personal $\left(\mathrm{X}_{3}\right)$. Hipotesis penelitian merupakan jawaban sementara 
terhadap rumusan masalah penelitian, dimana rumusan masalah penelitian telah dinyatakan dalam bentuk pertanyaan (Sugiyono, 2016:93). Berdasarkan rumusan masalah, tujuan penelitian, kajian teori serta hasil penelitian sebelumnya maka dapat ditarik hipotesis didalam penelitian berikut yaitu sebagai berikut.

Partisipasi didalam proses penyusunan anggaran untuk proses mengambil keputusan bersama-sama bagi beberapa pihak dimana keputusan itu akanlah mempunyai masa depan pada mereka yang membuat keputusan itu (Ikhsan dan Ishak, 2011:106). Ada atau tidaknya partisipasi anggaran, mampu memberikan karyawan agar mempunyai kesempatan dalam memberikan informasi yang diketahuinya ke atasannya, hingga atasannya nanti bisa membuat keputusan paling baik bagi perusahaannya. Ada tidaknya partisipasi yang betul tidak partisipasi semu didalam proses penganggaran bisa membuat pengurangan adanya slack (Yuliana \& Ratnadi, 2016). Didalam riset yang dilaksanakan oleh (Kristianto, 2009), didapatkan hasil bahwasannya partisipasi penganggaran memiliki pengaruh negatif pada senjangan anggaran. Hal tersebut berarti, makin tingginya tingkat partisipasi penganggaran jadi tingkat senjangan anggaran yang timbul juga merendah, serta begitu juga sebaliknya. Berdasarkan pemaparan atau penjelasan tersebut, maka di susun hipotesis seperti ini:

$\mathrm{H}_{1}$ : Partisipasi penganggaran berpengaruh negatif pada senjangan anggaran.

Perilaku gaya kepemimpinan (Leadership Behavior) merupakan cara-cara berinteraksi seorang pemimpin dalam melakukan kegiatan pekerjaannya. Bila pemimpin memiliki orientasi pada hubungan dimana pemimpin memiliki hubungan yang bagus dengan karyawannya, jadi karyawan bisa merasakan 
I Putu Suardi Antara Putra Mendi dan Herkulaus Bambang Suprasto. Pengaruh ...

kebebasan serta tidaklah takut jika mereka membuat suatu senjangan (Soekarso dan Putong, 2015:43-45). Paparan itu sesuai dengan hasil yang didapatkan Ikhsan (2007) juga Yunas (2010) memberi pernyataan bahwasannya gaya kepemimpinan mampu menguatkankan hubungan partisipasi anggaran pada senjangan anggaran. Namun tidak sama dengan hasil yang diperoleh Ramadhina (2007), Himawan serta Ika (2010), Widyaningsih (2011), juga Rosalina (2012) yang memberi pernyataan gaya kepemimpinan memiliki orientasi tugas bisa membuat lemah hubungan diantara partisipasi anggaran pada senjangan anggaran. Efektivitas partisipasi anggaran sangat dipengaruhi oleh gaya kepemimpinan manajemen (Mulia, 2006). Partisipasi kelompok atau individu yang efektif bergantung pada padanan yang tepat antara gaya interaksi dari si pemimpin dengan bawahan serta sampai tingkat mana situasi memberikan kendali dan pengaruh kepada si pemimpin. Berdasarkan pemaparan atau penjelasan tersebut, maka di susun hipotesis seperti ini:

$\mathrm{H}_{2}$ : Gaya Kepemimpinan memperkuat pengaruh partisipasi penganggaran pada senjangan anggaran.

Karakter personal yaitu persepsi individu tentang mampu tidaknya seseorang didalam melakukan tugasnya ataupun membuat suatu pencapaian. Karakter personal terpilih dikarenakan individu mempunyai sifat yang lain. Didalam riset berikut karakter personal terbagi jadi 2 sifat, dimana rasa optimis serta pesimis (Simon, 2008). Apabila mereka mempunyai rasa pesimis sedari awal, jadi mereka akanlah merasakan kesulitan didalam pencapaian target yang ditetapkan, hingga mereka akanlah cenderung membentuk sebuah senjangan. Penelitian sebelumnya yang memakai variable berikut yaitu Maksum (2009) yang 
mendapat hasil bahwasannya karakter personal bisa berpengaruh terhadap hubungan diantara partisipasi anggaran dengan senjangan anggaran. Berdasarkan hasil penelitian yang dilaksanakan oleh Maksum (2009) memberi pernyataan bahwasannya bila para bawahannya mempunyai karakter personal yang pesimis, jadi partisipasi anggaran akanlah memberi kenaikan senjangan anggaran. Berdasar pemaparan atau penjelasan tersebut, maka di susun hipotesis seperti ini:

H3: Karakter personal memperkuat pengaruh partisipasi penganggaran pada senjangan anggaran.

\section{METODE PENELITIAN}

Desain penelitian menguraikan tentang pendekatan yang cocok digunakan untuk mendapatkan jawaban masalah dan tujuan penelitian. Pendekatan yang digunakan dalam penelitian ini adalah pendekatan kuantitatif yang berbentuk asosiatif kausalitas. Penelitian asosiatif kausalitas merupakan penelitian yang bertujuan untuk mengetahui pengaruh antara dua variabel atau lebih (Sugiyono, 2016:55). Penelitian ini menguji hubungan variabel Partisipasi Penganggaran $\left(\mathrm{X}_{1}\right)$ dengan Senjangan anggaran $(\mathrm{Y})$ yang di moderasi oleh variabel Gaya Kepemimpinan $\left(\mathrm{X}_{2}\right)$ dan Karakter Personal $\left(\mathrm{X}_{3}\right)$. Hubungan kausalitas dapat diperjelas dengan memakai struktur teori agar membuat sebuah hipotesis, lalu hipotesis dilakukan pengujian dengan memakai analisis regresi moderasi yang diolah menggunakan aplikasi SPSS untuk mengetahui hasil dari hipotesis yang telah dibuat dan untuk mendapatkan simpulan. Secara rinci desain penelitian ini dapat dilihat pada uraian Gambar 2. sebagai berikut: 
I Putu Suardi Antara Putra Mendi dan Herkulaus Bambang Suprasto. Pengaruh ...

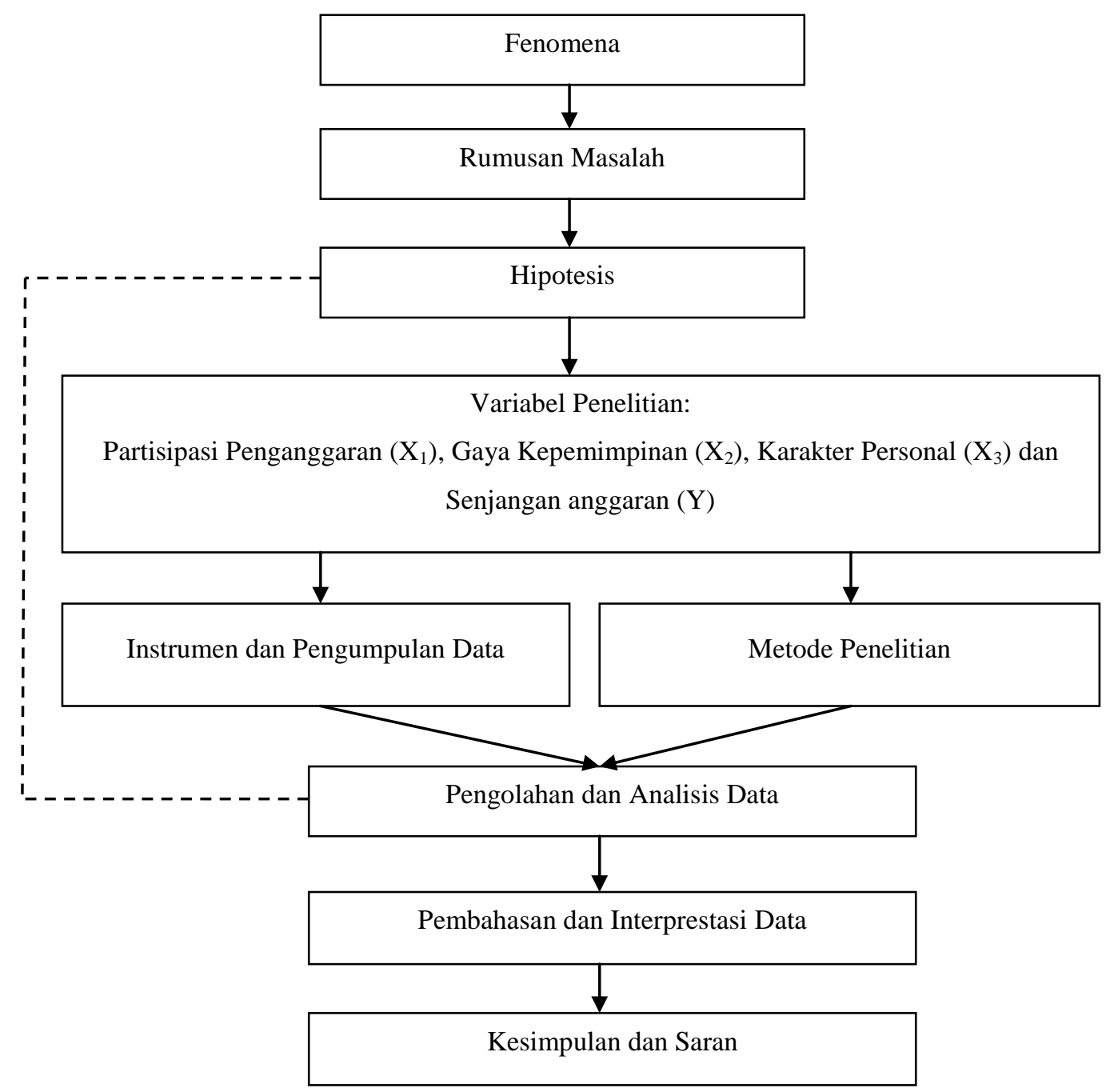

Sumber: Data Diolah, 2019

Gambar 2. Desain Penelitian

Lokasi riset dilaksankan di hotel berbintang pada Wilayah Ubud, Kabupaten Gianyar. Alasannya riset berikut dilaksanakan di hotel, dikarenakan biasanya hotel yang menggunakan manfaat anggaran berfungsi alat bantu manajemen dalam melaksanakan kinerja maksimum (Suprasto, 2006). Selain itu, hotel yang digunakan sebagai subjek penelitian adalah yang berlokasi di Ubud. Kawasan Ubud dipilih karena merupakan salah satu kawasan di Kabupaten Gianyar yang paling banyak menyediakan fasilitas pariwisata, lebih variatif, dan banyak dikunjungi oleh wisatawan mancanegara karena melakukan penyimpanan seni 
serta potensi alam yang sangatlah menarik untuk kita nikmati. Kaitannya lokasi penelitian ini dengan variabel penelitian yaitu karena ditemukan adanya indikasi terjadinya senjangan anggaran yang cukup tinggi di hotel berbintang di Kawasan Ubud.

Obyek penelitian didalam penelitian berikut yaitu senjangan anggaran di Hotel berbintang di Kawasan Ubud, Kabupaten Gianyar. Didalam penelitian berikut terdapat tiga jenis variabel yaitu variabel bebas, variabel terikat dan variabel moderasi. Variabel independent dalam penelitian ini adalah partisipasi penganggaran $\left(\mathrm{X}_{1}\right)$. Variabel terikat dalam penelitian ini adalah senjangan anggaran (Y). Didalam penelitian berikut variable moderasinya adalah Gaya Kepemimpinan $\left(\mathrm{X}_{2}\right)$ serta Karakter Personal $\left(\mathrm{X}_{3}\right)$.

Partisipasi anggaran diukur dengan menggunakan instrumen yang dikembangkan oleh (Milani, 1975) yang terdiri atas enam pertanyaan serta diukur dengan memakai skala likert 5 poin. Skala besar memberi petunjuk partisipasi anggaran yang besar serta skala kecil memberi petunjuk partisipasi anggaran yang kecil. Partisipasi Penganggaran terukur menggunakan 6 indikator seperti berikut. keterlibatan manajer, alasan atasan melakukan revisi anggaran, frekwensi memberikan usulan, pengaruh manager didalam anggaran akhir, penting tidaknya kontribusi yang diberi, frekwensi menyampaikan pendapat.

Senjangan anggaran dapat dilakukan pengukuran dengan memakai instrument penelitian berbentuk kuesioner yang dilakukan pengembangan oleh Karsam (2013) yang terdiri atas enam pernyataan serta terukur memakai skala likert 5 poin. Penelitian ini menggunakan teori yang dikembangkan oleh 
I Putu Suardi Antara Putra Mendi dan Herkulaus Bambang Suprasto. Pengaruh ...

(Dunk, 1993) dimana senjangan anggaran terukur dengan enam indikator variabel sebagai berikut. adanya dorongan meningkatkan produktivitas yang diakibatkan oleh standar yang diterapkan didalam anggaran, adanya keyakinan bahwasannya anggaran dalam departemen bisa dilaksanakan, adanya pengawasan pada pengeluaran disebabkan terbatasnya besaran anggaran, adanya anggapan bahwasannya anggaran yang jadi tanggung jawabnya tak begitu besar yang akan dituntut, besar tidaknya tingkat kesulitan didalam mencapai target anggaran membuat terjalannnya efisiensi, adanya anggapan bahwasannya sasaran yang terjabar didalam anggaran susah agar tercapai.

Didalam riset berikut, gaya kepemimpinan terukur dengan skala likert 5 point dengan 5 pernyataan yang diadopsi dari penelitian Lestiana (2016). Gaya kepemimpinan diukur dengan lima indikator sebagai berikut. Hubungan antara pemimpin dengan bawahan, cara mengambil keputusan, cara pandang, mengkomunikasikan tujuan, memberikan penghargaan. Hasil kuisioner dengan skala yang tinggi menunjukkan gaya kepemimpinan yang dianut oleh perusahaan adalah gaya berorientasi pada orang sedangkan sebaliknya apabila skala rendah maka gaya kepemimpinan yang dianut adalah gaya berorientasi pada tugas.

Variable karakter personal didalam riset berikut di ukur dengan memakai 4 biji pernyataan yang dilakukan adopsi dari riset yang di lakukan oleh Pradyadari serta Krisnadewi (2014) yang dilakukan pengukuran memakai skala likert 5 poin. Karakter personal terukur menggunakan empat indicator sebagai berikut. Keyakinan akan mampu atau tidaknya didalam melakukan penyelesaian tugas, keyakinan akan mampu atau tidaknya didalam mengatasi tantangan, pengalaman 
persaingan dengan karyawan lainnya, pandangan tentang dukungan yang didapatkan. Hasil kuisioner yang menunjukkan skala yang tinggi menunjukkan bahwa responden memiliki karakter personal optimistis, sedangkan sebaliknya apabila skala rendah menunjukkan responden memiliki karakter personal pesimistis.

Populasi responden didalam riset berikut yaitu semua manager ataupun kepala divisi yang dilibatkan langsung didalam proses menyusun anggaran di hotel berbintang di Kecamatan Ubud Kabupaten Gianyar, karena hampir seluruh hotel berbintang di Kecamatan Ubud memiliki pola struktur organisasi yang sama dengan jumlah manajer dan kepala divisi yang serupa. Metode penentuan sampel responden dalam penelitian ini menggunakan metode purposive sampling, yaitu metode pengumpulan informasi dari target-target tertentu atau orang-orang yang memberi informasi yang diperlukan peneliti karena mereka sesuai dengan kriteria yang ditentukan. Teknik pengambilan sampel dilakukan secara purposive sampling dengan tujuan untuk mendapatkan sampel yang representatif sesuai dengan kriteria yang telah ditentukan. Oleh karena jumlah sampel hotel berbintang yang berada di Kawasan Ubud Kabupaten Gianyar dalam penelitian ini sebanyak 20 hotel, dengan sampel responden yang memenuhi kriteria sebanyak 4 orang manager, maka jumlah responden yang digunakan sebagai sampel penelitian adalah sebanyak 80 orang.

Data kuantitatif pada penelitian ini adalah hasil kuesioner berupa angkaangka dari masing-masing jawaban responden pada variabel penelitian serta data mengenai jumlah dan persentase responden berdasarkan karakteristik yang terdiri 
I Putu Suardi Antara Putra Mendi dan Herkulaus Bambang Suprasto. Pengaruh ...

dari jenis kelamin, umur, tingkat pendidikan dan lama bekerja. Kuesioner yang disebarkan berupa daftar pernyataan tertulis kepada responden mengenai partisipasi penganggaran, senjangan anggaran, gaya kepemimpinan dan karakter personal. Data kualitatif dalam penelitian ini adalah berupa daftar nama hotel berbintang yang berada di Kawasan Ubud Kabupaten Gianyar dan pernyataan yang terdapat dalam kuesioner penelitian. Tiap-tiap variable itu dilakukan persiapan dengan jumlah pertanyaan yang memiliki perbedaan satu dengan yang lain. Berdasar sumber itu, data yang dipakai didalam riset berikut yaitu data primer berbentuk jawaban responden pada poin-poin pernyataan ataupun pertanyaan yang ada didalam instrument penelitian, adalah partisipasi penganggaran, senjangan anggaran, gaya kepemimpinan serta karakter personal. Untuk mendapatkan hasil penelitian yang valid dan reliabel maka harus menggunakan instrumen yang valid dan reliabel pula.

Penelitian berikut menggunakan variable gaya kepemimpinan serta karakter personal sebagai variable moderasi. Variable moderasi adalah variable bebas yang dapat memperbesar ataupun memperkecil hubungan diantara variable bebas lain pada variable terikat. Oleh sebab itu riset berikut memakai Uji interaksi ataupun sering pula dinamakan Moderated Regression Analysis (MRA) yaitu aplikasi yang mengkhusus regresi berganda linear, didalam persamaan regresi berunsur interaksi (Ghozali 2016: 223). Uji interaksi ataupun Moderated Regression Analysis (MRA) bisa kita hitung menggunakan persamaan seperti ini (Wijaya 2012: 138):

$$
\mathrm{Y}=\alpha+\beta_{1} \mathrm{X}_{1}+\beta_{2} \mathrm{X}_{1} \mathrm{X}_{2}+\beta_{3} \mathrm{X}_{1} \mathrm{X}_{3}+\epsilon
$$


Keterangan:

$\mathrm{Y} \quad=$ Senjangan anggaran

$\alpha \quad=$ Konstanta

$\beta_{1}-\beta_{3} \quad=$ Koefisien regresi

$\mathrm{X}_{1} \quad=$ Partisipasi Penganggaran

$\mathrm{X}_{1} \mathrm{X}_{2} \quad=$ Interaksi partisipasi Pengganggaran dengan Gaya Kepemimpinan

$\mathrm{X}_{1} \mathrm{X}_{3} \quad=$ Interaksi partisipasi Pengganggaran dengan Karakter Personal

$\mathrm{e} \quad=$ Error

$\beta_{1,} \beta_{2,} \beta_{3} \quad=$ Koefisien regresi

Tabel 1.

Klasifikasi Variabel Moderasi

\begin{tabular}{cll}
\hline No. & \multicolumn{1}{c}{ Tipe Moderasi } & \multicolumn{1}{c}{ Koefisien } \\
\hline 1. & Pure Moderasi & $\mathrm{b}_{2}$ non significant \\
& & $\mathrm{b}_{3}$ significant \\
\hline 2. & Quasi Moderasi & $\mathrm{b}_{2}$ significant \\
& & $\mathrm{b}_{3}$ significant \\
\hline 3. & Homologiser Moderasi & $\mathrm{b}_{2}$ non significant \\
& & $\mathrm{b}_{3}$ non significant \\
\hline 4. & Predictor Moderasi & $\mathrm{b}_{2}$ significant \\
& & $\mathrm{b}_{3}$ non significant
\end{tabular}

Sumber : Solimun, 2010:34

Variabel moderasi bisa terklasifikasi jadi empat jenis. Tiap-tiap klasikasi moderasi bisa teridentifikasi seperti contoh berikut, apabila $\mathrm{X}$ yaitu variable predictor, $\mathrm{Y}$ variable dependen serta $\mathrm{M}$ variable moderasi jadi persamaan regresi yang bisa terbentuk sepert ini :

$$
\mathrm{Y}=\beta_{1} \mathrm{X}_{1}+\beta_{2} \mathrm{M}_{1}+\beta_{3} \mathrm{X}_{1} * \mathrm{M}_{1}
$$

\section{HASIL DAN PEMBAHASAN}

Karakteristik responden riset berikut yaitu profil daripada 80 responden yang memiliki partisipasi didalam mengisi kuisioner. Karakteristik responden riset termasuk jenis kelamin, umur, jenjang pendidikan, serta lama bekerja. Besar 
I Putu Suardi Antara Putra Mendi dan Herkulaus Bambang Suprasto. Pengaruh ...

jumlah pegawai laki-laki sejumlah 43 orang responden $(53,75 \%)$ serta pegawai perempuan sejumlah 37 orang $(46,25 \%)$. Informasi ini memberikan gambaran bahwa responden yang merupakan karyawan pada hotel berbintang di Kawasan Ubud yang terlibat penyusunan maupun pelaksanaan anggaran mayoritas adalah karyawan laki-laki. Dalam riset berikut dari 80 responden penelitian, ada 10 orang $(12,50 \%)$ dengan umur 20-30 tahun, 19 orang $(23,757 \%)$ dengan umur 31-40 tahun, 45 orang $(56,25 \%)$ dengan umur $41-50$ tahun, dan 6 orang $(7,50 \%)$ dengan umur > 50 tahun. Responden yang mempunyai tingkat pendidikan Diploma sejumlah 34 orang $(42,50 \%)$, S1 sejumlah 41 orang $(51,25 \%)$ dan S2 sebanyak 5 orang $(6,25 \%)$. Data menunjukkan responden yang bekerja selama satu sampai lima tahun sejumlah 13 orang $(16,25 \%)$, yang bekerja selama enam sampai sepuluh tahun sejumlah 21 orang $(26,25 \%)$ dan responden yang lama bekerja lebih daripada puluhan tahun sejumlah 46 orang $(57,50 \%)$.

Statistik deskriptif memiliki tujuan dalam memberi info tentang karakteristik variable-variable penelitian adalah jumlah antara nilai minimal, nilai maksimal, nilai mean, serta standart deviasi. Dalam pengukuran nilai central daripada distribusi data bisa dilaksanakan memakai mengukur rata-rata (mean) namun standar deviasi merupakan berbedanya nilai data yang dilakukan penelitian memakai nilai rata-rata. Hasil statistika deskriptive bisa terlihat di Tabel 2. 
Tabel 2.

Hasil Statistik Deskriptif Variabel Penelitian

\begin{tabular}{lcrrrr}
\hline & N & Minimum & Maximum & Mean & Std. Deviation \\
\hline Partisipasi penganggaran & 80 & 8 & 30 & 20.66 & 6.036 \\
Gaya kepemimpinan & 80 & 10 & 25 & 19.59 & 3.648 \\
Karakter personal & 80 & 8 & 20 & 15.63 & 2.572 \\
Senjangan anggaran & 80 & 13 & 29 & 23.34 & 3.453 \\
Valid N (listwise) & 80 & & & &
\end{tabular}

Sumber : Data diolah, 2019

Berdasar kepada hasil uji statistik deskriptif di Tabel 2 bisa diketahui bahwasannya total sample yang dipakai yaitu 80 orang responden. Rentang kriteria untuk mengukur variabel dalam penelitian ini adalah sebagai berikut:

Nilai Interval : Skor maksimum - Skor minimun $=5-1=4$

Range $: \frac{\text { Nilai Interval }}{\text { Jumlah Kelas }}=\frac{4}{5}=0,80$

Skor pada penelitian ini memiliki nilai tertinggi maksimal 5 dan terendah minimal 1. Kriteria pengukuran tersebut menunjukkan bahwa semakin tinggi nilai rata-rata yang diperoleh menunjukkan semakin baik tanggapan responden terhadap item maupun variabel tersebut.

Variabel partisipasi penganggaran memiliki total nilai minimum sejumlah 8 serta total nilai maksimum sejumlah 30 . Variable partisipasi penganggaran yang terukur dengan 6 jenis pernyataan menggunakan skala likert 5 point mempunyai nilai rata-rata sejumlah 20,66, bila terbagi dengan 6 jenis pernyataan mampu memberikan nilai sejumlah 3,44 yang berarti rata-rata responden menjawab setuju dalam pertanyaan partisipasi anggaran. Hasil tersebut memiliki arti responden cenderung dalam melaksanakan partisipasi penganggaran sangat besar. Nilai standar deviasi variable partisipasi penganggaran sejumlah 6,036. Hal tersebut 
I Putu Suardi Antara Putra Mendi dan Herkulaus Bambang Suprasto. Pengaruh ...

memiliki arti nilai tersebut lebih kecil dibanding dengan nilai rata-rata, yang berarti sebaran data yang memiliki keterkaitan pada partisipasi penganggaran telah merata.

Variable gaya kepemimpinan memiliki total nilai minimum sejumlah 10 serta total nilai maksimum sejumlah 25. Variable gaya kepemimpinan yang terukur dengan 5 jenis pernyataan menggunakan skala likert 5 point mempunyai nilai rata-rata sejumlah 19,59 , bila terbagi dengan 5 point pertanyaan akanlah memberikan hasil besaran sejumlah 3,91 yang berarti rata-rata responden memberi jawaban setuju dalam pernyataan gaya kepemimpinan. Hasil tersebut memiliki arti cenderungnya responden memberikan nilai bahwasannya pimpinan pada tempat bekerjanya telah mempunyai gaya kepemimpinan yang terbaik. Nilai standar deviasi variable gaya kepemimpinan sejumlah 3,648. Hal tersebut memiliki arti besaran tersebut lebih kecil berbanding dengan nilai rata-rata, yang memiliki arti penyebaran data tersebut dengan gaya kepemimpinan telah rata.

Variable karakter personal mempunyai total nilai minimum sejumlah 8 serta total nilai maksimum sejumlah 20. Variable karakter personal yang terukur dengan 4 item pernyataan memakai skala likert 5 point mempunyai nilai rata-rata sejumlah 15,63, bila dibagi dengan 4 item pernyataan dapat memberikan hasil nilai sejumlah 3,90 yang memiliki arti rata-rata responden memberi jawaban setuju bagi pernyataan karakter personal. Hal tersebut memiliki arti kecenderungan responden sudah memiliki karakter personal yang bagus. Nilai standar deviasi variable karakter personal sejumlah 2,572. Hal tersebut memiliki 
arti besaran tersebut lebih kecil berbanding dengan nilai rata-rata, yang berarti penyebaran data memiliki keterkaitan dengan karakter personal telah rata.

Tabel 3. Hasil Uji Validitas

\begin{tabular}{cccc}
\hline Variabel & Indikator & Koefisien Korelasi & Keterangan \\
\hline & $\mathrm{X}_{1.1}$ & 0,687 & Valid \\
& $\mathrm{X}_{.1 .2}$ & 0,909 & Valid \\
Partisipasi penganggaran $\left(\mathrm{X}_{1}\right)$ & $\mathrm{X}_{1.3}$ & 0,873 & Valid \\
& $\mathrm{X}_{.1 .4}$ & 0,896 & Valid \\
& $\mathrm{X}_{.1 .5}$ & 0,888 & Valid \\
& $\mathrm{X}_{.1 .6}$ & 0,822 & Valid \\
& $\mathrm{X}_{2.1}$ & 0,825 & Valid \\
Gaya kepemimpinan $\left(\mathrm{X}_{2}\right)$ & $\mathrm{X}_{2.2}$ & 0,834 & Valid \\
& $\mathrm{X}_{2.3}$ & 0,858 & Valid \\
& $\mathrm{X}_{2.4}$ & 0,877 & Valid \\
& $\mathrm{X}_{2.5}$ & 0,527 & Valid \\
& $\mathrm{X}_{3.1}$ & 0,502 & Valid \\
& $\mathrm{X}_{3.2}$ & 0,824 & Valid \\
& $\mathrm{X}_{3.3}$ & 0,740 & Valid \\
& $\mathrm{X}_{3.4}$ & 0,725 & Valid \\
& $\mathrm{Y}_{1}$ & 0,758 & Valid \\
& $\mathrm{Y}_{2}$ & 0,797 & Valid \\
& $\mathrm{Y}_{3}$ & 0,658 & Valid \\
& $\mathrm{Y}_{4}$ & 0,760 & Valid \\
& $\mathrm{Y}_{5}$ & 0,486 & Valid \\
\hline & $\mathrm{Y}_{6}$ & 0,535 &
\end{tabular}

Sumber : Data diolah, 2019

Variable senjangan anggaran memiliki total nilai minimum sejumlah 13 serta total nilai maksimum sejumlah 29. Variable senjangan anggaran yang terukur dengan 6 item pernyataan menggunakan skala likert 5 point mempunyai nilai rata-rata sejumlah 23,34, bila terbagi dengan 6 item pernyataan akanlah memberikan hasil nilai sejumlah 3,89 yang berarti rata-rata responden memberi jawaban setuju agar pertanyaan senjangan anggaran. Hasil tersebut memiliki arti cenderungnya responden dalam melaksanakan senjangan anggaran cukup besar. Nilai standar deviasi variabel senjangan anggaran sejumlah 3,453. Hasil tersebut 
I Putu Suardi Antara Putra Mendi dan Herkulaus Bambang Suprasto. Pengaruh ...

memiliki arti nilai tersebut lebih rendah dibanding dengan nilai rata-rata, yang berarti penyebaran data terkait dengan senjangan anggaran telah rata.

Uji validitas digunakan untuk mengukur sah atau tidaknya suatu kuesioner. Suatu instrument diyatakan valid apabila korelasi diantara skor faktor dengan skor total memiliki nilai positif serta mempunyai nilai lebih daripada $0,30(\mathrm{r}>0,3)$. Hasil uji validitas bisa dilihat di Tabel 3.

Uji reliabilitas dilaksanakan agar memberi petunjuk sejauh mana sebuah alat bisa dipercaya. Sebuah instrumen dinyatakan reliabel, bila instrumen itu mempunyai nilai Alpha Cronbach lebih dari 0,60. Hasil uji reliabilitas bisa terlihat di Tabel 4.

Tabel 4.

Hasil Uji Reliabilitas

\begin{tabular}{clcc}
\hline No. & \multicolumn{1}{c}{ Variabel } & Cronbach's Alpha & Keterangan \\
\hline 1 & Partisipasi penganggaran $\left(\mathrm{X}_{1}\right)$ & 0,807 & Reliabel \\
2 & Gaya kepemimpinan $\left(\mathrm{X}_{2}\right)$ & 0,802 & Reliabel \\
3 & Karakter personal $\left(\mathrm{X}_{3}\right)$ & 0,776 & Reliabel \\
4 & Senjangan anggaran $(\mathrm{Y})$ & 0,766 & Reliabel \\
\hline
\end{tabular}

Sumber : Data diolah, 2019

Hasil pengujian reliabilitas di Table 4 memberikan petunjuk bahwasannya seluruh instrumment penelitian memiliki koefisien Cronbach's Alpha melebihi 0,60. Hal tersebut mampu menyatakan bahwasannya seluruh instrument reliabel hingga bisa dipakai agar melaksanakan penelitian.

Uji normalitas mempunyai tujuan supaya dapat mengetahui apakah residual daripada model regresi yang dibentuk memiliki distribusi normal ataupun tidak. Agar uji apa data yang terpakai normal ataukah tidak mampu dilaksanakannya dengan memakai uji Kolmogorov Sminarnov. Jika koefisien Asymp. Sig. (2- 
tailed) melebihi besar daripada 0,05 walaupun data tersebut dinyatakan mempunyai distribusi normal.

Tabel 5.

Hasil Uji Normalitas

\begin{tabular}{llr}
\hline & One-Sample Kolmogorov-Smirnov Test & \\
\hline & & $\begin{array}{c}\text { Unstandardized } \\
\text { Residual }\end{array}$ \\
\hline $\mathrm{N}$ Normal Parameters ${ }^{\mathrm{a}, \mathrm{b}}$ & Mean & 80 \\
& Std. Deviation & .0000000 \\
Most Extreme Differences & Absolute & 2.08732266 \\
& Positive & .051 \\
& Negative & .041 \\
Kolmogorov-Smirnov Z & & -.051 \\
Asymp. Sig. (2-tailed) & & .458 \\
Sumber: Data diolah, 2019 & & .985 \\
\hline
\end{tabular}

Berdasar kepada Tabel 5 bisa terlihat bahwasanya nilai Kolmogorov Sminarnov (K-S) senilai 0,458, namun besaran Asymp. Sig. (2-tailed) senilai 0,985. Hasil tersebut memberikan indikator bahwasanya model persamaan regresi tersebut mempunyai distribusi normal karena besaran Asymp. Sig. (2-tailed) 0,985 melebihi besar dari pada nilai alpha 0,05 . Uji heteroskedastisitas memiliki tujuan agar memberitahu apa didalam model regresi adanya ketidaksamaan varians daripada residual satu pengamatan kepada pengamatan lain yang dilaksanakan dengan uji Glejser. Apabila tak adanya satu variable independen yang mempunyai pengaruh signifikan pada nilai absolute residual ataupun nilai signifikansi diatas 0,05 maka tak memiliki gejala heteroskedastisitas.

Pada Tabel 6 bisa terlihat bahwasannya nilai signifikansi daripada variable partisipasi penganggaran sejumlah 0,551 , Gaya kepemimpinan sejumlah 0,475 , karakter personal sejumlah 0,755 , variable interaksi X1.X2 sejumlah 0,833 serta variable interaksi X1.X3 sejumlah 0,118. Hasil itu melebihi 0,05 yang memiliki 
I Putu Suardi Antara Putra Mendi dan Herkulaus Bambang Suprasto. Pengaruh ...

arti tak ada pengaruh diantara variable independent pada absolute residual. Dengan begitu, model yang terbuat tidaklah mengalami gejala heteroskedastisitas.

Tabel 6.

Hasil Uji Heteroskedastisitas

\begin{tabular}{lrrrrr}
\hline & \multicolumn{2}{c}{ Unstandardized Coefficients } & Standardized Coefficients & & \\
\cline { 2 - 5 } & $\mathrm{B}$ & Std. Error & Beta & $\mathrm{t}$ & Sig. \\
\hline (Constant) & 2.376 & 1.623 & & 1.464 & .148 \\
Partisipasi penganggaran & .024 & .040 & .111 & .598 & .551 \\
Gaya kepemimpinan & -.040 & .056 & -.112 & -.718 & .475 \\
Karakter personal & .022 & .070 & .043 & .314 & .755 \\
Interaksi X1.X2 & .000 & .002 & .035 & .212 & .833 \\
Interaksi X1.X3 & -.003 & .002 & -.288 & -1.582 & .118 \\
\hline Sumber: Data diolah, 2019 & & & & &
\end{tabular}

Proses uji data didalam penelitian tersebut memakai tehnik analisis regresi moderasi. Penghitungan koefisien regresi moderasi dilaksanakan dengan analisis regresi lewat software SPSS 18.0 for Windows, didapatkan hasil yang ditampilkan di Tabel 7 seperti:

Tabel 7.

Hasil Analisis Regresi Moderasi

\begin{tabular}{|c|c|c|c|c|c|}
\hline \multirow{2}{*}{ Model } & \multicolumn{2}{|c|}{$\begin{array}{c}\text { Unstandardized } \\
\text { Coefficients }\end{array}$} & \multirow{2}{*}{$\begin{array}{c}\begin{array}{c}\text { Standardized } \\
\text { Coefficients }\end{array} \\
\text { Beta }\end{array}$} & \multirow{2}{*}{ Sig. } & \multirow{2}{*}{ Keterangan } \\
\hline & B & $\begin{array}{c}\text { Std. } \\
\text { Error }\end{array}$ & & & \\
\hline (Constant) & 16,644 & 2,671 & & 0,000 & \\
\hline Partisipasi Penganggaran & $-0,283$ & 0,066 & $-0,494$ & 0,000 & $\mathrm{H}_{1}$ diterima \\
\hline Gaya Kepemimpinan & 0,154 & 0,092 & 0,163 & 0,098 & \\
\hline Karakter Personal & 0,238 & 0,115 & 0,177 & 0,043 & \\
\hline Interaksi X1.X2 & 0,006 & 0,003 & 0,230 & 0,027 & $\mathrm{H}_{2}$ diterima \\
\hline Interaksi X1.X3 & 0,008 & 0,003 & 0,339 & 0,004 & $\mathrm{H}_{3}$ diterima \\
\hline R Square & & & & 0,635 & \\
\hline Adjusted R Square & & & & 0,610 & \\
\hline F Statistik & & & & 25,700 & \\
\hline Signifikansi & & & & 0,000 & \\
\hline
\end{tabular}

Sumber : Data diolah, 2019

Berdasar kepada hasil analisis regresi linier berganda seperti yang tersaji di

Table 7, jadi persamaan struktural yaitu seperti ini: 
$Y=16,644-0,283 X_{1}+0,154 X_{2}+0,238 X_{3}+0,006 X 1 \cdot X 2+0,008 X 1 \cdot X 3+e$

Interpretasi dari persamaan di atas adalah sebagai berikut: 1) Nilai konstanta sebesar 16,644 yaitu jika partisipasi penganggaran $\left(\mathrm{X}_{1}\right)$, Gaya kepemimpinan $\left(\mathrm{X}_{2}\right)$, karakter personal $\left(\mathrm{X}_{3}\right)$, interaksi partisipasi penganggaran dengan Gaya kepemimpinan serta interaksi partisipasi penganggaran dengan karakter personal sama dengan nol, hingga besaran senjangan anggaran adalah tetap sejumlah 16,644. 2) Koefisien regresi partisipasi penganggaran sejumlah $-0,283$ hasil $P_{\text {value }}$ 0,000 artinya setiap kenaikan partisipasi penganggaran senilai 1 satuan akan menyebabkan penurunan pada senjangan anggaran sebesar 0,283 , dengan asumsi variabel bebas lainnya tetap. 3) Koefisien regresi gaya kepemimpinan sebesar 0,154 dengan $\mathrm{P}_{\text {value }} 0,098$ artinya setiap kenaikan gaya kepemimpinan senilai 1 satuan dapat menyebabkan peningkatan di senjangan anggaran sejumlah 0,154 , dengan asumsi variable independen lain tetap. 4) Koefisien regresi karakter personal sejumlah 0,238 dengan $\mathrm{P}_{\text {value }}$ 0,043 artinya setiap kenaikan karakter personal senilai 1 satuan dapat menyebabkan peningkatan di senjangan anggaran senilai 0,238, dengan asumsi variable independen lain tetap. 5) Koefisien regresi interaksi X1.X2 sebesar 0,006 dengan $\mathrm{P}_{\text {value }}$ 0,027 artinya setiap kenaikan interaksi X1.X2 senilai 1 satuan dapat menyebabkan peningkatan di senjangan anggaran sejumlah 0,006, dengan asumsi variable independen lain tetap. 6) Koefisien regresi interaksi X1.X3 senilai 0,008 dengan $\mathrm{P}_{\text {value }} 0,004$ artinya setiap kenaikan karakter personal senilai 1 satuan akanlah menyebabkan meningkatnya senjangan anggaran senilai 0,008, dengan berasumsi variable independen lain tetap. 
I Putu Suardi Antara Putra Mendi dan Herkulaus Bambang Suprasto. Pengaruh ...

Hasil uji F (Ftest) pada Tabel 7 memberi petunjuk bahwasannya nilai signifikansi $\mathrm{P}_{\text {value }} 0,000$ lebih kecil daripada $\alpha=0,05$, hasil tersebut memiliki arti model yang dipakai di riset berikut merupakan layak. Hasil itu memberikan arti bahwasanya semua variable independen bisa melakukan prediksi ataupun memberikan penjelasan fenomena senjangan anggaran pada Hotel Berbintang kawasan Ubud. Dengan kata lain partisipasi penganggaran ( $\left.\mathrm{X}_{1}\right)$, Gaya kepemimpinan $\left(\mathrm{X}_{2}\right)$, karakter personal $\left(\mathrm{X}_{3}\right)$, interaksi partisipasi penganggaran dengan Gaya kepemimpinan serta interaksi partisipasi penganggaran dengan karakter personal secara simultan memiliki pengaruh signifikan terhadap senjangan anggaran pada Hotel Berbintang kawasan Ubud. Hal ini berarti model fix karena variabel independen dapat menjelaskan variabel dependen.

Hasil uji memberi hasil dimana didapatkan besar adjusted $\mathrm{R}^{2}$ (koefisien determinasi yang sudah disesuaikan) di Table 7 yaitu 0,610. Itu memiliki arti variasi senjangan anggaran dapat dijelaskan oleh variabel partisipasi penganggaran $\left(\mathrm{X}_{1}\right)$, Gaya kepemimpinan $\left(\mathrm{X}_{2}\right)$, karakter personal $\left(\mathrm{X}_{3}\right)$, interaksi X1.X2 dan interaksi X1.X3 sebesar 61 persen, namun sisa sebanyak 39 persen diberikan penjelasan oleh faktor-faktor lainnya yang tak dimasukkan kedalam model penelitian.

Berdasar uji statistik pengaruh partisipasi penganggaran pada senjangan anggaran menunjukkan koefisien regresi sebesar $-0,283$ dengan $P_{\text {value }} 0,000$. Hasil uji tersebut menunjukkan partisipasi penganggaran mempunyai pengaruh negatif dan signifikan pada senjangan anggaran. Berdasarkan uji statistik tersebut maka $\mathrm{H}_{1}$ diterima. Hasil uji konsisten dengan penelitian Ikhsan (2007) serta Kristianto 
(2009). Berdasarkan uji statistik menunjukkan interaksi X1.X2 antara partisipasi anggaran dengan gaya kepemimpinan memberikan petunjuk koefisien regresi 0,006 dengan $\mathrm{P}_{\text {value }}$ 0,027. Hasil uji itu memberikan petunjuk gaya kepemimpinan memperkuat hubungan partisipasi anggaran dengan senjangan anggaran. Berdasarkan uji statistik tersebut maka $\mathrm{H}_{2}$ diterima. Hasil uji konsisten dengan penelitian Ikhsan (2007), Simon (2008), dan Yunas (2010). Berdasarkan uji statistik memberi petunjuk interaksi X1.X3 diantara partisipasi anggaran dengan karakter personal memberikan petunjuk koefisien regresi 0,008 dengan $\mathrm{P}_{\text {value }}$ 0,004. Hasil uji itu memberikan petunjuk karakter personal memperkuat hubungan partisipasi anggaran dengan senjangan anggaran. Berdasar uji statistik tersebut maka $\mathrm{H}_{3}$ diterima. Hasil uji konsisten dengan penelitian Simon (2008) dan Maksum (2009).

Hasil analisis regresi menunjukkan koefisien regresi partisipasi penganggaran mempunyai tanda negatif dengan $\mathrm{P}_{\text {value }} 0,000<0,05$, hal tersebut menunjukan bahwasannya partisipasi penganggaran mempunyai pengaruh negatif terhadap senjangan anggaran di Hotel Berbintang kawasan Ubud. Hasil itu menunjukkan bahwasannya makin besar tingkat partisipasi didalam penganggaran jadi tingkat senjangan anggaran di Hotel Berbintang kawasan Ubud akan mengalami penurunan. Begitu juga sebaliknya semakin rendah tingkat partisipasi dalam penganggaran maka tingkat senjangan anggaran di Hotel Berbintang kawasan Ubud akan mengalami peningkatan.

Keterlibatkan manajer didalam penyusunan anggaran, akanlah memberi penambahan info untuk atasan tentang lingkungan yang sedang serta yang dapat 
I Putu Suardi Antara Putra Mendi dan Herkulaus Bambang Suprasto. Pengaruh ...

dihadapi dan memberikan bantuan penyelesaian masalah yang terkait dengan anggaran. Partisipasi pula bisa memberikan pengurangan tekanan dan kegelisahan di bawahannya. Hasil tersebut dikarenakan manager bisa memberitahu sebuah tujuan yang relevan, yang bisa diterima serta bisa tercapai. Keikut sertaan didalam penyusunan anggaran adalah sebuah cara efektif dalam membentuk keselarasan tujuan tiap-tiap pertanggungjawaban dengan tujuan organisasi secara umum. Partisipasi akanlah terarah di komunikasi yang positive, dikarenakan dengan partisipasi akanlah kejadian mekanisme bertukarnya info. Jika partisipasi didalam proses penyusunan anggaran terjadi peningkatan jadi akan memungkinkan terjadinya senjangan anggaran yang mengecil. Hasil penelitian ini didukung dengan penelitian yang dilaksanakan oleh Arfan (2011) dan Kristianto (2009) yang mendapatkan hasil bahwasannya partisipasi penganggaran memiliki pengaruh negatif pada senjangan anggaran. Hasil tersebut berarti, makin meningkatnya tingkat partisipasi penganggaran sehingga tingkat senjangan anggaran yang timbul dapat makin kecil, serta begitu juga sebaliknya.

Hasil analisis regresi moderasi menunjukkan bahwa gaya kepemimpinan secara statistik mampu memoderasi pengaruh partisipasi penganggaran terhadap senjangan anggaran. Di riset berikut, gaya kepemimpinan memberi penguatan pengaruh partisipasi penganggaran terhadap senjangan anggaran. Hal ini memberikan petunjuk apabila manajer memiliki gaya kepemimpinan yang baik, adalah pemimpin memiliki hubungan baik dengan bawahan, maka karyawan pasti segan serta berusaha bekerja dengan maksimal sesuai target yang ditetapkan, sehingga peran karyawan saat berpartisipasi didalam penyusunan anggaran 
akanlah semakin meminimalisir timbulnya senjangan anggaran. Sebaliknya, apabila manager memiliki gaya kepemimpinan yang tidak baik atau otoriter, maka karyawan akan merasa terbebani dalam mencapai target yang ditetapkan, sehingga peran karyawan saat berpartisipasi dalam penyusunan anggaran akan mampu meningkatkan terjadinya senjangan anggaran.

Hasil penelitian ini didukung oleh temuan Simon (2008) yang menyatakan bahwa gaya kepemimpinan mampu menjadi moderasi pengaruh partisipasi penganggaran terhadap senjangan anggaran. Jika seseorang pemimpin mampu menumbuhkan rasa optimis atau percaya diri dalam diri karyawannya, maka karyawan akanlah merasakan mudah dalam pencapaian tujuan yang ditentukan, hingga karyawan tersebut akanlah cenderung meminimalisir terjadinya senjangan anggaran. Hasil penelitian ini juga didukung oleh riset dari Ikhsan (2007) serta Yunas (2010) yang memberikan pernyataan bahwasannya gaya kepemimpinan memberi penguatan hubungan partisipasi anggaran pada senjangan anggaran.

Hasil analisis regresi moderasi menunjukkan bahwa karakter personal secara statistik mampu memoderasi pengaruh partisipasi penganggaran terhadap senjangan anggaran. Pada penelitian ini, karakter personal memperkuat pengaruh partisipasi penganggaran terhadap senjangan anggaran. Hal ini menunjukkan apabila karyawan mempunyai karakter personal yang pesimis, jadi peran karyawan saat berpartisipasi dalam penyusunan anggaran akan semakin meningkatkan timbulnya senjangan anggaran. Sebaliknya, apabila karyawan memiliki karakter personal yang optimis, maka karyawan akan percaya diri dan mudah dalam pencapaian tujuan yang ditentukan, hingga peran pegawai saat 
I Putu Suardi Antara Putra Mendi dan Herkulaus Bambang Suprasto. Pengaruh ...

berpartisipasi dalam penyusunan anggaran akan mampu meminimalisir terjadinya senjangan anggaran.

Hasil penelitian ini didukung oleh temuan Simon (2008) yang memberikan pernyataan bahwasannya karakter personal mampu melakukan moderasi pengaruh partisipasi penganggaran di senjangan anggaran. Apabila seseorang mempunyai rasa pesimis sedari awal, jadi dia akanlah merasakan kesulitan dalam pencapaian tujuan yang ditentukan, hingga dia akankah memiliki kecendrungan penciptaan sebuah senjangan. Hasil riset berikut juga terdukung oleh penelitian Maksum (2009) yang mendapatkan hasil bahwa karakter personal dapat mempengaruhi hubungan antara partisipasi anggaran dengan senjangan anggaran. Artinya, apabila para bawahan memiliki karakter personal yang pesimis, maka partisipasi anggaran akan menaikkan senjangan anggaran.

\section{SIMPULAN}

Simpulan yang dapat diberikan berdasarkan hasil penelitian yang dilakukan yaitu: Partisipasi penganggaran berpengaruh negatif dan signifikan pada senjangan anggaran. Gaya Kepemimpinan memperkuat pengaruh partisipasi penganggaran pada senjangan anggaran. Karakter personal memperkuat pengaruh partisipasi penganggaran pada senjangan anggaran.

Berdasarkan hasil penelitian, analisis, serta kesimpulan di atas, maka saran yang dapat diberikan sebagai berikut: Saran yang dapat diberikan untuk pihak yang terlibat dalam penyusunan anggaran pada hotel berbintang di Kecamatan Ubud yaitu manajer sebaiknya lebih meningkatkan kualitas karakter personal 
bawahannya dan meningkatkan gaya kepemimpinan menjadi lebih baik agar dapat mengurangi senjangan anggaran yang terjadi di perusahaan, Hasil statistik deskriptif menunjukkan jawaban responden yang memiliki nilai paling rendah terdapat pada pernyataan "atasan selalu menyampaikan alasannya saat merevisi penyusunan anggaran di perusahaan", maka daripada itu disarankan pada manajer atau atasan untuk dapat menyampaikan alasannya saat merevisi penyusunan anggaran di perusahaan pada bawahannya, agar karyawan mengetahui letak kesalahan yang dibuat, sehingga senjangan anggaran dapat diminimalisir, Bagi penelitian selanjutnya diharapkan dapat memperluas ruang lingkup wilayah penelitian tidak hanya pada lingkup hotel berbintang di kawasan ubud saja, melainkan mencakup lingkup daerah yang lebih luas misalnya dengan melakukan penelitian di seluruh Kabupaten Gianyar ataupun di seluruh Bali, sehingga dapat mewakili populasi dengan jumlah yang lebih besar, Penelitian selajutnya disarankan untuk menambahkan variabel bebas ataupun variabel moderasi lainnya untuk menunjang kompleksitisitas penelitian, misalnya menambahkan variabel dukungan manajemen, iklim kerja etis ataupun self esteem, komitmen organisasi, budaya organisasi, penekanan anggaran.

\section{REFERENSI}

Anggraini, R., \& Sulistyowati, I. (2010). Pengaruh Profitabilitas, Leverage, dan Growth Terhadap Kebijakan Dividen dengan Good Corporate Governance sebagai Variabel Intervening. Simposium Nasional Akuntansi XIII Purwokerto, 6(2), 103.

Anissarahma, Dini. 2008. Pengaruh Partisipasi Anggaran, Informasi Asimetris, Budget Emphasis dan Komitmen Organisasi Terhadap Timbulnya Slack 
I Putu Suardi Antara Putra Mendi dan Herkulaus Bambang Suprasto. Pengaruh ...

Anggaran (Studi Kasus Pada PT. Telkom Yogyakarta). Yogyakarta. Simposium Nasional VII.

Antle, R. dan Eppen, G.D. 1985. Capital Rationing and Organizational Slack in Capital Budgeting. Management Science 31 (February). Pp.163-174.

Anthony, R.N. dan Govindarajan, V. 2001. Management Control System. Edisi 11. Salemba Empat. Jakarta.

Brownell, P. 1982. The Role of Accounting Data in Performance Evaluation. Budgetary Partisipative, and Organizational Effectiveness. Journal of Accounting Reseacrh. Vol. 20, pp: 12-27.

Baiman, S. 1982. Agency research in managerial accounting: A survey. Journal of Accounting Literature 1 (Spring): 154-213.

Camman, C. 1976. Effects of the use of control system. Accounting , Organizations and Society 14: 301-13.

Collins F. 1978. The Interaction of Budget Characteristics and Personality Variables with Budgetary Response Attitudes. The Accounting Review. Pp: 324-335.

Darlis, Edfan. 2002. Analisis Pengaruh Komitmen Organisasi dan Ketidakpastian Lingkungan Terhadap Hubungan Antara Partisipasi Anggaran dengan Senjangan Anggaran. Jurnal Akuntansi Indonesia. Vol. 5, No. 1.

Dunk. Alan S. 1993. The Effect of Budget Emphasis and Information Asymetry on The Relation Between Budgetary Participation and Slack. The Accounting Review, pp: 400-410.

Eisenhardt, Kathleen M. 1989. Agency Theory : An Assessment and Review. The Academy of Management Review, Vol. 14, No.1 (Jan.,1989), pp.57-74.

Falikhatun. September 2007. "Pengaruh Partisipasi Penganggaran Terhadap Budgetary slack dengan Variabel Pemoderasi Ketidakpastian Lingkungan dan Kohesivitas Kelompok".Jurnal Akuntansi dan Keuangan Universitas Muhammadiyah Surakarta, Volume 6, No. 2, Halaman 207 - 221.

Falikhatun. 2007. Interaksi Informasi Asimetri. Budaya Organisasi dan Group Cohesiveness dalam Hubungan Antara Partisipasi Penganggaran dan Budgetary slack. Symposium Nasional Akuntansi X.

Lucyanda, Jurica. 2018. Budget Sebagai Alat Evaluasi Kinerja Manajerial. Jurnal Akuntansi Fakultas Ekonomi UNISA. Hal : 80-90 
Grediani, Evi dan Sugiri, Slamet. 2010. Pengaruh Tekanan Ketaatan dan Tanggung Jawab Persepsian pada Penciptaan Budgetary slack. Simposium Nasional Akuntansi XIII. Purwekerto 2010.

Ghozali, Imam. 2016. Aplikasi Analisis Multivariate Dengan Program IBM SPSS 22. Edisi 7. Semarang: Universitas Diponegoro

Govindarajan, V. 1986. Impact Of Participation In The Budgetary Process On Management Attitudes And Performance : Universalistic And Contigency Perspectives. Decision Sciences, pp: 496-516.

Hansen, D.R. dan M.M. Mowen. 1997. Management Accounting, International Editions, McGraw-Hill.

Ikhsan, Arfan dan Ane, La. 2007. Pengaruh Partisipasi Anggaran terhadap Senjangan Anggaran dengan Menggunakan Lima Variabel Pemoderasi. Simposium Nasional Akuntansi X. Unhas Makasar 26-28 Juli.

Ikhsan. Arfan dan Ishak. Muhamad. 2011. Akuntansi Keperilakuan. Jakarta: Salemba Empat.

Ghozali, Imam. 2016. Aplikasi Analisis Multivariate Dengan Program IBM SPSS 23. Semarang: Badan Penerbit Universitas Diponegoro

Indrawati Yuhertiana. 2009. Menggalai Peluang Baru Penelitian di Ranah Akuntansi Keperilakuan Sektor Publik. Seminar Nasional. Fakultas Ekonomi UPN Veteran Jawa Timur.

Jensen, M. dan Meckling W. 1976. Theory of The Firm: Managerial Behavior, Agency Cost And Ownership Structure. Journal of Financial Eco-nomics. 3: $305-360$

Kartika, Andi. 2010. Pengaruh Komitmen Organisasi dan Kepastian Lingkungan dalam Hubungan antara Partisipasi Anggaran dengan Senjangan Anggaran. Jurnal Kajian Akuntansi, 2(1), pp:39-60.

Kenis, 1979. Effect on Budgetary Goal Karakteristik On Managerial Attitude and Performance. The Accounting Review. LIV(4): 707-721.

Karsam, 2013. The Influence of Participation in Budgeting on Budgetary slack with Information Asymetry as a Moderating Variable and 1st Impact on the Managerial Performance (A Study on Yayasan Pendidikan dan Koperasi in the Province of Banten. Indonesia). International journal of Applied Finance and BusinessStudies. 1(I). Hlm. 28-38. 
I Putu Suardi Antara Putra Mendi dan Herkulaus Bambang Suprasto. Pengaruh ...

Lestari, Tri. 2014. Pengaruh Anggaran Partisipatif Pada Senjangan Anggaran Dengan Ketidakpastian Lingkungan Dan Komitmen Organisasi Sebagai Variabel Pemoderasi. Skripsi. Fakultas Ekonomi dan Bisnis Universitas Udayana.

Lowe, E.A. dan R.W. Shaw. 1968. An Analysis of Managerial Biasing: Evidence From a Company's Budgeting Proses. The Journal of Management Studies 5. Oktober. Hal 304-315.

Lucyanda, Jurica. 2018. Budget Sebagai Alat Evaluasi Kinerja Manajerial. Jurnal Fakultas Ekonomi Unisma. Hal: 80-90

Lukka, K. 1988. Budgetary Biasing in Organizations: Theoritical Framework and Empirical Evidence. Accounting, Organization, and Society 13. Hal. 281301.

Luthans, Fred. 2002. Organizational Behavior Ninth Edition. McGraw-Hill. New York.

M. Nafarin. 2009. Penganggaran Perusahaan. Edisi 3. Jakarta: Salemba Empat.

Milani, K. 1975. The Relationship of Participation in Budget Setting to Industrial Supevisor Performance Attitudes : A. Field Study. Accounting Revie. April. pp: 274-284.

Mulyadi. 2001. Sistem Akuntansi. Edisi ke 3. Penerbit Salemba Empat. Jakarta.

Negara, Putu Ryan Sutha., dan I Gde Ary Wirajaya. 2018. Pengaruh Partisipasi Penyusunan Anggaran pada Budgetary slack dengan Komitmen Organisasi, Opportunistic Behavior dan Ketidakpastian Lingkungan Sebagai Pemoderasi. E-Jurnal Akuntansi Universitas Udayana. 22(3). Hal: 2339-2367

Onsi. M. 1973. Facktor Analysis of Behavioral Variables Affecting Budgetary slack. The Accounting Review, pp: 535-548.

Peoni, Herianus. 2013. Pengaruh Karakteristik Individu Dan Lingkungan Kerja Terhadap Kinerja Karyawan (Studi Pada PT. Taspen (Persero) Cabang Manado). Jurnal Administrasi Bisnis. Fakultas Ilmu Sosial dan Politik Universitas Sam Ratulangi

Siegel, G dan Marconi, H. Ramanauskas. 1989. Behavioural Accounting. South Western Publishing Company. 
Siti, Mahmodha Almalifah. 2005. Analisis Karakteristik Individu dan Karakteristik Organisasi terhadap Pengembangan karir Pegawai di Kanwil Bea Dan Cukai Surabaya. Tesis. Universitas Airlangga

Soekarso dan Putong, Iskandar. (2015). Kepemimpinan: Kajian Teoritis dan Praktis. Bogor: Mitra Wacana Media

Solimun. 2010. Analisis Multivariat Pemodelan Struktural Metode Partial Least Square- PLS. Penerbit CV. Citra: Malang

Stede, Wim A. Van der. 2000. The Relationship Between Two Consequences of Budgetary Controls: Budgetary slack Creation and Managerial ShortTerm Orientation. Accounting, Organizations and Society. Vol.25, 609622.

Sugiwardani, Resti. 2012. "Analisis Pengaruh Partisipasi Anggaran, Informasi Asimetri, Budaya, dan Komitmen Organisasi terhadap Budgetary slack"(tesis). Surabaya. Sekolah Tinggi Ilmu Ekonomi Perbanas.

Sugiyono. 2016. Metodologi Penelitian Kuantitatif, Kualitatif, dan R\&D. Bandung: CV Alfabeta.

Suprasto, Bambang. 2006. "Pengaruh Interaksi Antara Partisipasi Anggaran, Informasi Asimetris, dan Penekanaan Anggaran terhadap Budgetary slack (Studi Kasus di Hotel-Hotel di Provinsi Bali)". Audi Jurnal Akuntansi dan Bisnis. Vol. 1. Hal 75-86.

Veronica, Amelia dan Krisnadewi, Komang Ayu. 2009. Pengaruh Partisipasi Penganggaran, Penekanan Anggaran, Komitmen Organisasi dan Kompleksitas Tugas terhadap Slack Anggaran pada Bank Perkreditan Rakyat (BPR) di Kabupaten Badung.

Wijaya, Tony. 2012. "SPSS 20 untuk Olah dan Interpretasi Data” Cahaya Atma Pustaka. Yogyakarta.

Young, S.M.1985. "Participative Budgeting: The Effect of Risk Aversion and Assymetric Information on Budgetary slack". Journal of Accounting Research, Vol. 23: 829-842.

Yuliana, M., \& Ratnadi, N. M. D. (2016). Pengaruh Partisipasi Penganggaran Pada Kesenjangan Anggaran Dengan Ambiguitas Peran Sebagai Variabel Pemoderasi. E-Jurnal Akuntansi Universitas Udayana, 16(1), 781-811. https://doi.org/10.1002/eji.201444988.This 